\title{
Fundamental Rights of States in International Law and the Right to Peaceful Nuclear Energy
}

\author{
Daniel H Joyner*
}

\begin{abstract}
This article first discusses the overall theme of this special issue of the Cambridge Journal of International and Comparative Law from a legal theoretical perspective, namely, the concept of the fundamental rights of states in international law. It concludes that fundamental rights of states exist in international law as autonomous juridical principles. The article then proceeds to discuss one such asserted fundamental right of states: the right to peaceful nuclear energy, as codified in the 1968 Nuclear Non-proliferation Treaty. It argues that the right to peaceful nuclear energy is indeed a fundamental right of states, and that it has juridical substance, and carries juridical implications, as a rule of law on par with other rules of the jus dispositivum.
\end{abstract}

\section{Keywords}

Fundamental Rights of States, Nuclear Non-Proliferation Treaty, Right to Peaceful Nuclear Energy, Security Council

\section{Introduction}

In this paper, I will first discuss the overall theme of this special issue of the Cambridge Journal of International and Comparative Law - the concept of the fundamental rights of states in international law-from a legal theoretical perspective. I will conclude that fundamental rights of states exist in international law as autonomous juridical principles. I will, then, proceed to discuss one such asserted fundamental right of states: the right to peaceful nuclear energy, as codified in the 1968 Nuclear Non-proliferation Treaty. ${ }^{1}$ I will argue that the right to peaceful nuclear energy is indeed a fundamental right of states,

* Professor of Law, University of Alabama School of Law (USA). I wish to thank all of the participants in the workshop held at the University of Alabama, School of Law, in April 2015, for their invaluable discussion and feedback on these ideas, and Sahib Singh for his excellent editorial comments and suggestions. I would also like to thank Dean Mark Brandon of the University of Alabama, School of Law, for financially supporting the workshop and this project.

1 Treaty on the Non-proliferation of Nuclear Weapons (adopted 1 July 1968, entered into force 5 March 1970) 729 UNTS 161 (NPT). 
and that it has juridical substance, and carries juridical implications, as a rule of law on par with other rules of the jus dispositivum.

\section{Fundamental rights of states in international law}

There is no question that states have international legal rights. The primary and secondary sources of international law that were identified in the introduction to this special issue and in section two, consisting primarily of treaties and United Nations (UN) General Assembly resolutions, amply demonstrate that states generally accept as a reality the concept that they have international legal rights in addition to their international legal obligations. $^{2}$

The questions that this special issue has grappled with flow from this initial descriptive observation. These questions include: what, then, is the legal character of these rights? What is their source? What is their juridical nature, and what are their juridical implications?

The concept of states' rights must be understood in a historical context. The papers in section one of this special issue are extremely useful in demonstrating that this concept has been an enduring one in international legal thought, and that in every era of the history of international law, however those eras are defined, the concept of states' rights has been present and has performed a particular function.

The most recent reiteration of and re-emphasis on the concept of states' fundamental rights in international law can be seen to have occurred in the second half of the twentieth century, when most of the primary and secondary sources of international law identifying rights of states were created. There appears to have been a particular concentration of these sources, including both treaties and UN General Assembly resolutions, between the 1950s and the 1970s. These decades were marked by, among other geopolitical developments, the phenomenon of decolonisation, resulting in a wave of new assertions of independence and sovereign prerogative by historically exploited and marginalised developing states in the Middle East, Africa, South Asia, and South America. ${ }^{3}$

These newly independent states were generally keen to make their mark on the international legal system into which they were newly emerging and to reform it from its Eurocentric foundations. In a number of issue areas, notably also including the Law

2 Daniel H Joyner and Marco Roscini, 'Is There Any Room for the Doctrine of Fundamental Rights of States in Today's International Law?' (2015) 4 CJICL 467; Convention on Rights and Duties of States (adopted 26 December 1933, entered into force 26 December 1934) 165 LNTS 19 (Montevideo Convention); Charter of the Organization of American States (adopted 30 April 1948, entered into force 3 December 1948) 119 UNTS 3; Charter of the United Nations (signed 26 June 1945, entered into force 24 October 1945) 1 UNTS XVI (UN Charter); UN, Yearbook of the International Law Commission 1949 (1956) 287-90; UNGA Res 2625(XXV) (24 October 1970); UNGA Res 3171(XXVIII) (17 December 1973); UNGA Res 3281(XXIX) (12 December 1974); UNGA Res 36/1039 (10 December 1981).

3 See Antony Anghie, Imperialism, Sovereignty and the Making of International Law (CUP 2005) ch 4. 
of the Sea, these states worked to re-frame the sources of international law in order to provide for a counterbalancing of leverage and a protection of their interests against the political and economic power of the developed world. ${ }^{4}$

This, then, is the historical context in which so many of the treaties and UN General Assembly resolutions asserting rights of states were created. Again, this concept was not a new one. In fact, it had a long conceptual pedigree. But it was being reinvented at this particular historical moment for this particular political purpose. So what did the states that inserted these provisions espousing states' rights into treaties and UN General Assembly resolutions during this time think that they were doing? Did they think that they were creating, or re-creating, a separate class of international legal norms with an autonomous substance and with real and efficacious juridical meaning and implications? Or were they simply drawing on older language that was intrinsically connected to concepts of natural law and state sovereignty and that had a powerful anthropomorphic connection to human rights, the other ascendant international legal principle of the day? Or was it some combination of these ideas?

This is a difficult question to answer on the basis of records of UN General Assembly statements and the travaux préparatoires of the relevant treaties. This is primarily because one finds very little discussion of the concept of fundamental rights of states from a theoretical perspective in these materials. The idea of states having rights has been a basic principle of the international legal system in the consciousness of both diplomats and international legal scholars since the very beginnings of international legal thought, as again demonstrated by the papers in section one of this special issue. Likely because of the self-evident nature of this concept and its long pedigree in conceptions of the international legal order, it appears that when these sources of positive law were being created in the decades following the Second World War, their drafters did not consider it necessary to specify precisely the legal import of the rights they were asserting.

And indeed, the precise juridical nature and implications of rights of states only really 'matter' in a practical sense, in cases in which a right of a state comes into conflict, either with the obligations of the right holder or with the rights or obligations of some other actor in the international legal system. And since those occasions are relatively rare, there has been little focused consideration of these questions by either diplomats or legal scholars.

Another factor in the paucity of serious thinking on this question is, in my opinion, that powerful states, who also tend to have a disproportionate influence either de facto or de jure in international organisations, typically have little use for 'fundamental rights of states' talk. As a rule, powerful states prefer to focus on international legal duties instead of rights, mostly on the duties of others to be more specific. The idea of inalienable, inherent, fundamental rights inuring in all states is one that can only potentially blunt the legal, political and economic power and influence of powerful states. Rather, these

4 See Robin Churchill and Vaughan Lowe, The Law of the Sea (3rd edn, Manchester UP 1999) 16. 
states typically find their interests better served by focusing only on legal obligations and on using their various forms of power to pressure weaker states to accept such obligations in forms advantageous to their own self-interest.

Thus, states' rights talk is generally one sided on the part of developing states. For their part, international legal scholars in developed states often either do not notice such talk when it occurs or instinctively give it little notice, as simply the resistance vocabulary of the disenfranchised.

In my opinion, however, the concept of fundamental rights of states and the questions asked by the papers in this special issue go straight to the heart of the very modern struggle for the soul of the international legal system. They consider both descriptive and normative questions about how we both do and should understand the structure and content of sources of international law, and the legal relations between holders of international legal personality. In particular, as mentioned in the introduction to this special issue, the questions considered herein about the concept of states' rights are vital to our understanding of the legal relationship and authority dynamics between states and international organisations in particular. As such, they tie powerfully into debates concerning the role of international organisations in the international legal system as well as to literature on the constitutionalisation of international law. ${ }^{5}$

Before proceeding further, a semantic issue should be addressed. In historical scholarly literature, the idea of states' rights was typically expressed along with the prefacing adjective 'fundamental.' 6 Other adjectives are also frequently seen in both scholarly literature and positive legal sources to accompany assertions of states' rights. These include inter alia 'inherent', 'inalienable', and 'permanent'. Much could be written about these respective adjectives and the additional meaning they were intended to bestow upon both the essential concept of rights of states and upon discrete assertions of specific states' rights by their authors. While not wishing to diminish the value of such investigations by not engaging with them herein, I am most interested in, and would like to address further in this article, the essential question of rights of states as a concept in and of itself.

With regard specifically to the adjective 'fundamental', this added concept has always been central to advocates of states' rights, in conveying a message about the link between states' rights and the sovereignty of states per se. For many historical writers, the 'fundamentalness' of states' rights had strong links to their naturalistic conception of the sources and bases of international law. ${ }^{7}$ For some writers, including Ricardo Alfaro whose work is discussed in the introduction to this special issue, a distinction

5 See, eg, José Alvarez, International Institutions as Law Makers (OUP 2006); Jeffrey Dunoff and Joel Trachtman (eds), Ruling the World? Constitutionalism, International Law and Global Governance (CUP 2009).

6 See the articles in section one of this special issue of the CJICL.

7 Georg Friedrich de Martens, Précis du Droit des Gens Moderne de l'Europe (Guillaumin et cie Libraire 1858). 
was further drawn between fundamental rights, on the one hand, and non-fundamental rights (in Alfaro's terms 'acquired rights'), on the other hand. ${ }^{8}$

While the natural law underpinnings of the concept of rights of states in international law in much of historical scholarship is clear, the concept of rights of states both can and should be viewed in the modern context as one that has its basis exclusively in positivistic sources of international law, in much the same way as customary international law has evolved in our understanding of its juridical nature. ${ }^{9}$ The rights of states do not therefore necessarily emanate in a naturalistic fashion from states' sovereignty. Rather, rights should be seen to be created in the same way that obligations are understood to be created, through established sources of international law and in particular through customary international law. ${ }^{10}$

Returning to the question of 'fundamentalness', this additional concept was also used in historical scholarship to identify a few core rights of states that could be distinguished from the concept of the residual domaine réservé of states and be viewed as positive, autonomous and independent normative principles that could be asserted by states both as a sword and a shield depending upon context, and that had real and effective juridical implications. In this sense, there remains some usefulness in the added 'fundamentalness' concept for the rights of states. For this reason, and in order not to complicate this analysis by introducing an additional variable of moving away from conventional semantic use, I will retain general use of the adjective 'fundamental' when referring to the rights of states in international law, notwithstanding the fact that there are few other particular benefits, and some possible complications, arising from maintaining its connection to states' rights.

One such complication is the implication arising from the use of this additional adjective, that there is something particularly 'fundamental' about either all rights of states, or only some. This is the distinction and differentiation of juridical nature as between fundamental and acquired rights that Ricardo Alfaro made in his seminal work on the subject. ${ }^{11}$ As appealing as Alfaro's taxonomy of states' rights is, I have found it difficult to maintain such a distinction and the normative hierarchy that it implies, while

8 Ricardo J Alfaro, 'The Rights and Duties of States' (1959) II Recueil des Cours 116; Joyner and Roscini (n 1) 467.

9 See Stephen Hall, 'The Persistent Spectre: Natural Law, International Order and the Limits of Legal Positivism' (2001) 12 EJIL 269.

10 Hans Kelsen, General Theory of Law and State (Harvard UP 1945) 249-50: 'The so-called fundamental rights and duties of the States are rights and duties of the States only in so far as they are stipulated by general international law, which has the character of customary international law.

11 Alfaro (n 8) 104, 112 (emphasis in original):

Do fundamental rights of the State exist?, asks Le Fur. (...) My answer (...) is unhesitatingly in the affirmative, for I find myself unable to conceive a State divested of the four rights of independence, sovereignty, equality and self-preservation, or any one of them. Whether called attributes, qualities, competencies, powers, norms or rights, the conclusion seems inescapable that these are the fundamental rights of every State, from which emanate all the other rights that have been variously called subjective, eventual, secondary, accessory and, most aptly, acquired, since they have been acquired by customs or by treaty. 
keeping to the view that rights of states emanate exclusively from positivistic sources of international law and do not, for example, implicate the principle of jus cogens. I will therefore proceed with an understanding that all rights of states are hierarchically equal and are all best described using the conventional, though imperfectly descriptive moniker, 'fundamental rights of states'.

Where a fundamental right of states has been asserted through positive legal sources and where that right has been supported by state practice and opinio juris such that it is accepted as a principle of customary international law, it should be understood to comprise an independent rule of international law with juridical implications equal to any international legal obligation. This is the most honest and deferential way to understand what the states who created the treaties and other primary and secondary sources of international law asserting states' rights in the most recent revival of that concept meant to do, and indeed did.

Thus, when the framers of the Charter of the United Nations (UN Charter) in 1945 provided in article 51 that states have an 'inherent right' to self-defence, they were both recognising and creating this right as an autonomous rule of international law, which was then universalised through its acceptance as a rule of customary international law. Similarly, as is discussed in more detail below, when the 190 states parties to the Treaty on the Non-proliferation of Nuclear Weapons (NPT) agreed in article IV(1) that states have an 'inalienable right' to peaceful nuclear energy, they were both recognising and creating this right as an autonomous rule of international law and intended for this rule to have a legal meaning and implication at least on a par with any other obligation created through treaty or customary law. As with the right of self-defence, the right to peaceful nuclear energy became accepted in parallel customary law, and was thus universalised as a right of all states.

One of the questions that has been discussed at length in this special issue is what the idea of fundamental rights of states should be understood to add to the normative functioning of the international legal system. Specifically, should states' rights be understood to have a meaning and function coextensive with the concept of the Lotus principle in international law or the concept of the domaine réservé of national legal authority? Or, rather, should we understand the concept of states' rights to comprise, as Niki Aloupi has well described in her contribution to this special issue, an 'autonomous existence' as a category of international legal rules that is 'independent of [a] correlative prohibition' and that is separate from yet equal in normative hierarchy to international legal obligations? ${ }^{12}$

The states that negotiated for the recognition of an 'inherent right' of self-defence and an 'inalienable right' to peaceful nuclear energy in multilateral treaties and proclaimed other fundamental rights in UN General Assembly resolutions meant exactly what they were saying and intended these asserted rights to be understood as having an autonomous and efficacious legal character. They did not mean for these recitations to

12 Niki Aloupi, 'The Righ to Non-intervention and Non-interference' (2015) 4 CJICL 566, 567-68. 
be understood simply as normatively hollow rhetorical devices, to be used primarily as a method of argumentation and delimitation of the scope of corresponding obligations of others. On this matter, therefore, I very respectfully disagree with those who have maintained some version of this latter argument in their excellent contributions to this special issue-for example with Stephen Neff's conclusion that '[f]or better or worse, there is no theoretical or principled limit to the reach of international law, comparable to the privileged categories of liberties that exist in national constitutions. ${ }^{13}$

Now, it might be argued that I am here engaged in unsubstantiated speculation about what these states intended. And it is true that very little in the way of records from the travaux préparatoires of any of these sources exists to explicitly indicate what the general sense of the drafters of these instruments was on the question of the nature and implications of the fundamental rights they were asserting. Nevertheless, this argument is not baseless. Again, as the section one papers have amply demonstrated, the idea that states have rights in international law is one that has been present in the general conception of international law for centuries, and all of the international lawyers and diplomats who were engaged in the creation of these sources would have regarded this idea as a given aspect of the implications of state sovereignty-one that needed no justification or explanation.

And what was it that they thought such rights meant? While this question is historically debatable in its nuance, as a minimum it must be acknowledged that the concept of states having fundamental legal rights has always carried with it an understanding that these rights had juridical substance and meaning and were not simply rhetorical devices. Jean d'Aspremont in his contribution to this special issue persuasively links the idea of fundamental states' rights to anthropomorphism and to the concept of individual human or civil legal rights. ${ }^{14}$ This being the case, it seems most plausible that, just as individual rights were understood (at least by the late twentieth century) to have independent juridical substance, power and efficacy within their own legal context, so the concept of states' rights, psychologically related as it was, would have been understood to have meaningful juridical implications, and not to simply exist as the incorporeal shadow of others' obligations.

To assume that assertions of fundamental states' rights in the twentieth century treaties and UN General Assembly resolutions under examination represented something less than assertions of autonomous and effective legal rules is to engage in a much more tenuous and unsubstantiated speculative exercise and marginalisation of

13 Stephen C Neff, 'The Dormancy, Rise and Decline of Fundamental Liberties of States' (2015) 4 CJICL 482, 500.

14 Jean d'Aspremont, 'The Doctrine of Fundamental Rights of States and Anthropomorphic Thinking in International Law' (2015) 4 CJICL 501. As the author observes (at 507):

What matters is to highlight that the construction of a set of rights (and duties) of states was originally directed at the consolidation of a vision of an international society whose main units are abstract entities. Those units all ought to have their minimal space and freedom for such an international society to be viable and credible. These were the functions informing the anthropomorphic moves found in international legal thinking. 
historical context than is represented in these arguments. So again, when an assertion of a fundamental right of states becomes supported by state practice and opinio juris and is accepted as a rule of customary international law, it constitutes a rule of international law on full parity with jus dispositivum international legal obligations. Furthermore, once established, a right of states in international law creates an obligation of respect for that right in other states, and by extension in international organisations. Hans Kelsen has explained this aspect in more theoretical depth:

It is usual to distinguish between a right to one's own behavior and a right to the behavior of another. To say that a (physical or juristic) person has a right to behave in a certain way may mean only that there is no duty of this person to behave in another way. This, however, implies that all the other persons have the duty to refrain from preventing the subject of the 'right' to behave in this way. The right to one's own behavior is always the right to the behavior of others. But we speak of a right that a person has to the behavior of another in a specific sense of the term if a definite other person has the duty to behave in a certain way in relation to the subject of the right. A person has a right to the behavior of another person only if the other person has the duty to behave in this way. Finally, the term 'right' is used in its narrowest, technical sense if it designates the legal power conferred upon a person to bring about, by an action brought before a court, the execution of a sanction provided by the law in case another person violates his obligation to behave in a certain way in relation to the subject of the right. Hence, the right of one person always presupposes the corresponding duty of another person. In the first two cases mentioned the legal situation is completely described by a statement referring to the duty. The right of the one is but the reflection of the duty of another. Under general international law, only rights in this sense exist, since general international law does not institute courts. (...) The rights of states under general international law are always the reflection of the duties imposed by general international law upon other states. ${ }^{15}$

Thus, rights of states should be understood to create in third parties a legal obligation to respect those rights. This means that other states and international organisations are under an international legal obligation not to act in serious prejudice of fundamental states' rights. The precise contours of this obligation will be dictated by the contours of the legal right that has been established.

This aspect of the juridical implications of states' rights is particularly important in areas in which there is not in any other source of positive law an obligation on other states and international organisations to limit or prohibit their actions with regard to

15 Hans Kelsen, 'The Draft Declaration on Rights and Duties of States: Critical Remarks' (1950) 44 AJIL 259, 264 (emphasis in orginal). See also Alfaro (n 8) 104, 112:

Sovereignty implies the duty of every State to respect the rights emanating from it, pursuant to international law. Independence imposes on all States the basic duty of nonintervention. Equality creates an obligation for each State to render to every other State on equal terms that which is due to them by reason of their International Personality; and to recognize and accept from each of them all such lawful acts as are equal to those performed by all members of the Family of Nations. Selfpreservation rests upon the reciprocal duty of every State not to injure, impair or destroy the integrity of any State nor to violate any of its legal rights. 
the subject matter of the right. This subject will be retuned to and illustrated with an example in the context of the Nuclear Suppliers Group (NSG).

Finally, as mentioned previously, an understanding of the effectiveness of states' rights as autonomous, independently efficacious rules of international law is most important when a fundamental right of states comes into conflict with an obligation of the right holder or of some other holder of international legal personality. This understanding is particularly important when a fundamental right of states comes into conflict with the actions of international organisations, which are often not a party to multilateral treaties establishing positive legal obligations limiting their actions. I will return to this subject below and provide an example in the context of the UN Security Council's decisions regarding Iran's nuclear programme.

\section{The right to peaceful nuclear energy}

With this consideration of international legal theory on the principle of the fundamental rights of states in place, I will now proceed to consider one specific assertion of such a right-the right to peaceful nuclear energy, as codified in the NPT. As stated in the introduction to this special issue, the right to peaceful nuclear energy, which is recognised in article IV(1) of the NPT, is where my interest in the subject of the fundamental rights of states in international law originated. ${ }^{16}$

On its face, the idea that the right to peaceful nuclear energy should be classified in the same category as principles like self-defence, non-intervention, and permanent sovereignty over natural resources sounds unpersuasive. Frankly, the subject of the asserted right—nuclear energy_ just does not sound 'fundamental' enough in the life of a state. Nevertheless, the text of article IV(1) of the NPT does provide as follows: 'Nothing in this Treaty shall be interpreted as affecting the inalienable right of all the Parties to the Treaty to develop research, production and use of nuclear energy for peaceful purposes without discrimination and in conformity with Articles I and II of this Treaty'.

In the context of the NPT, article IV(1) is an important part of the 'Grand Bargain' which the NPT effectively codifies as between the nuclear weapon states parties to the treaty, and the non-nuclear weapon states parties. Along with article IV(2), which proceeds to place an obligation on advanced nuclear states to assist developing states in their peaceful nuclear endeavours, and article VI, which obligates all NPT parties to move towards complete nuclear disarmament in good faith, the NPT's recognition in article IV(1) is one of the chief concessions sought by developing non-nuclear weapon states in the NPT in exchange for their obligations never to acquire nuclear weapons, and to submit their civilian nuclear programmes to International Atomic Energy Agency (IAEA) safeguards.

16 Joyner and Roscini (n 1) 467. 
The inclusion of a right to peaceful nuclear energy in the NPT text, and its categorisation as an 'inalienable' right must be understood in the context of the time of the treaty's drafting. In the late 1960s, nuclear energy was widely considered to be the answer to the world's energy problems. ${ }^{17}$ The perceived potential for nuclear energy was expressed by Lewis Strauss, Chairman of the United States (US) Atomic Energy Commission, in 1955 in the following utopian terms:

It is not too much to expect that our children will enjoy in their homes electrical energy too cheap to meter; will know of great periodic regional famines in the world only as matters of history; will travel effortlessly over the seas and under them and through the air with a minimum of danger and at great speeds, and will experience a lifespan far longer than ours, as disease yields and man comes to understand what causes him to age. This is the forecast of an age of peace. ${ }^{18}$

Not everyone at the time agreed with Strauss' idyllic forecast, but there was a very strong current of opinion, at the highest political levels, that nuclear energy would play an integral role in helping all countries, and particularly developing countries, to meet their increasing energy needs and to facilitate their development and prosperity. It was on the basis of this recognition that US President Dwight Eisenhower proposed the creation of the IAEA in 1958, to act as an international nuclear fuel bank which would serve as an intermediary in providing nuclear fuel to developing countries, sourced primarily from blended down nuclear warhead cores donated by the US and the Union of Soviet Socialist Republics (USSR). Eisenhower referred to this as his Atoms for Peace' plan. ${ }^{19}$

At the time of the signing of the NPT in 1968, therefore, much of the world saw nuclear energy as a vital element in their future energy production portfolio, and one that provided unequalled potential in facilitating the development of the poorer regions of the globe. This is why the non-nuclear weapon states parties to the NPT lobbied so hard for the inclusion of article IV in the NPT, a treaty that started out merely as a nuclear weapons non-proliferation treaty masterminded by the two superpowers, the US and the USSR. But in exchange for their promise not to acquire or manufacture nuclear weapons, developing non-nuclear weapon states demanded that their residual ability to fully engage in the peaceful uses of nuclear energy be recognised, particularly by the superpowers, as an inalienable right that could not be taken away from them. ${ }^{20}$

When considering the question of the juridical nature of the right to peaceful nuclear energy, it is important to view this concept in its holistic context and not in isolation. For developing states in the 1960s, as well as for most states at all developmental stages

17 See Daniel H Joyner, Interpreting the Nuclear Nonproliferation Treaty (OUP 2011) 9-11.

18 See 'Abundant Power from Atom Seen; It will be Too Cheap for our Children to Meter, Strauss Tells Science Writers' New York Times (New York, 17 September 1954) 5.

19 Dwight D Eisenhower, 'Atoms for Peace' (8 December 1953) <http://voicesofdemocracy.umd.edu/ eisenhower-atoms-for-peace-speech-text/> accessed 3 April 2016.

20 See Joyner, Interpreting the Nuclear Nonproliferation Treaty (n 17) 17. 
today, increasing energy needs and strategies for meeting those needs are among the most important public policy priorities. Choices for each state regarding their energy production and trade portfolio are complex and specialised to their own circumstances. But for many states, nuclear energy is still seen as playing an integral part in their longterm energy plan. Both the International Energy Agency and the IAEA's forecasts for the coming decades predict both an increase in overall nuclear power production and an increase in the share of nuclear energy in worldwide electricity production. ${ }^{21}$ The growth of nuclear energy is predicted to be greatest in Eastern Europe, the Middle East and East Asia, with India and China both making substantial investments in new nuclear power plants over the next thirty years. ${ }^{22}$

The point is simply that many developing countries continue to see nuclear energy as one necessary element in their energy production portfolio, and as being vital to their development and prosperity. In this sense, there are strong connections between the right to peaceful nuclear energy and other rights and principles that are generally perceived as fundamental to states. For many states, for example, nuclear energy entails their own natural resources, ie uranium, being mined from their own territories and its potential use in nuclear power reactors. This, then, taps into a sense of permanent sovereignty over natural resources and their exploitation-a principle considered more fully by Yogesh Tyagi in this special issue. ${ }^{23}$

For developing states in particular, the right to peaceful nuclear energy also strongly taps into their sense of a right to non-interference in their internal affairs, a principle considered more fully by Niki Aloupi in this special issue, as well as to core considerations of energy security and energy independence, which they associate with their fundamental sovereign rights. ${ }^{24}$ There is ample evidence from the diplomatic records of review conferences associated with the NPT that any perceived encroachment upon the freedom of exercise of the right to peaceful nuclear energy has been met with vigorous protestation by the mostly developing states making up the Non-Aligned Movement. The 120 states comprising the Non-Aligned Movement made this point clearly in their August 2012 Plenary Summit Declaration:

All states should be able to enjoy the basic and inalienable right to the development, research, production and use of atomic energy for peaceful purposes, without any discrimination and in conformity with their respective international legal obligations. Therefore, nothing should be interpreted in a way to inhibit or restrict the right of states to develop nuclear energy

21 International Energy Agency, 'World Energy Outlook 2014 Factsheet-Nuclear Power: Retreat, Revival or Renaissance?’ (12 November 2014) <https://www.iea.org/media/news/2014/press/141112_WEO_ FactSheet_Nuclear.pdf> accessed 21 November 2015; Jeffrey Donovan, 'IAEA sees Global Nuclear Power Capacity Expanding in Decades to Come' (8 September 2015) <https://www.iaea.org/newscenter/news/ iaea-sees-global-nuclear-power-capacity-expanding-decades-come > accessed 3 April 2016.

22 International Energy Agency (n 21).

23 Yogesh Tyagi, 'Permanent Sovereignty over Natural Resources' (2015) 4 CJICL 588.

24 Aloupi (n 12). 
for peaceful purposes. States' choices and decisions, in the field of peaceful uses of nuclear technology and their fuel cycle policies (...) must be respected. ${ }^{25}$

Viewing the right to peaceful nuclear energy not in isolation, but in its context as an issue-specific manifestation of broader rights and concepts, including the right to permanent sovereignty over natural resources, the right to non-interference and fundamental considerations of energy security and independence, aids in understanding why the states parties to the NPT, now numbering 190, have agreed that all states possess an inalienable right to peaceful nuclear energy.

In this paper, the author would like to focus on the discrete question of the juridical nature and juridical implications of the 'inalienable right' which article IV(1) recognises. ${ }^{26}$

\subsection{Juridical nature}

The states parties to the NPT have uncontroversially recited the text of article IV(1) in their written submissions to NPT Preparatory Committee and Review Conference meetings, and in consensus NPT Review Conference Final Documents, ever since the treaty's coming into force in $1972 .{ }^{27}$ While there have been disagreements at these meetings, and as expressed in Conference Final Documents regarding the particulars of scope and application of the article IV(1) text, the text itself has been universally acknowledged and accepted in consensus statements and no serious dissent, in either words or actions, has ever been registered to the article IV(1) text as written.

There is a compelling argument to be made, therefore, that in addition to its provision in the NPT text itself, the fundamental right to peaceful nuclear energy, as expressed in article IV(1) of the NPT, has also passed into parallel customary international law. While the same cannot be said of all of the provisions of the NPT, some of which are not addressed to the universal membership of the NPT (eg, articles I and II), article IV(1) is explicitly addressed to 'all the Parties to the Treaty', and is therefore susceptible to the sort of state practice and opinio juris necessary for the establishment of customary law.

One possible caveat to this conclusion is, however, the very fact that the text of article $\mathrm{IV}(1)$ does by its terms at least, limit its recognition of the right as being applicable to the parties to the treaty and not to all states whether NPT parties or not. This explicit limitation in the text of article IV may give pause to some in considering whether a right, recognised in a broadly-subscribed-to multilateral treaty, and yet limited by the treaty text to the parties to the treaty itself, can pass into customary international law, and thereby become binding upon all states.

25 16th Summit of Heads of State or Government of the Non-Aligned Movement, 'The Final Declaration of the XVI Summit of Heads of State or Government of the Non-Aligned Movement' (31 August 2012) <http:// www.iranwatch.org/sites/default/files/nam-iransummitfinaldocument-083112.pdf> accessed 3 April 2016.

26 See, generally, Joyner, Interpreting the Nuclear Nonproliferation Treaty (n 17) 78-95, extensively exploring the interpretation and application of art IV(1) in its context within the NPT and in light of the treaty's object and purpose.

27 ibid 83, 121. 
Either explicitly or implicitly, any obligation or right established by a treaty applies only to the parties to the treaty. The concept of parallel customary law is that the parties to a treaty, who have taken upon themselves specific obligations or rights through that conventional instrument, can through subsequent parallel state practice and opinio juris create in customary law the same obligation or right that is contained in the treaty text. ${ }^{28}$ In light of the continuous and widespread acknowledgment of the text of article IV(1) of the NPT outlining a right to peaceful nuclear energy by the parties to the NPT, which comprise 190 states, its frequent assertion in diplomatic communications and the lack of any meaningful dissent in word or action to the principle as contained in article IV(1) by any state since 1972, I would conclude that the principle embedded in that article, defined by the text of article IV(1), has indeed passed into customary international law.

\subsection{Two interpretive points}

I do not wish to go into great detail on issues of interpretation and applied meaning of the article IV(1) right to peaceful nuclear energy. However, it is necessary here to briefly address a couple of interpretive points that have a direct bearing on this present analysis regarding the nature and juridical implications of the fundamental right to peaceful nuclear energy.

The first of these interpretive points addresses the closing words of article IV(1) of the NPT: 'in conformity with Articles I and II of this Treaty'. This clause of article IV(1) has been interpreted to be best read in accordance with the meaning associated with the phrase 'as limited by', by which it is meant that the right to peaceful nuclear energy recognised by article IV(1) must be understood to be limited by the obligation on all NPT non-nuclear weapon states contained in article II of the NPT, not to manufacture or otherwise acquire nuclear weapons. ${ }^{29}$

28 ibid 129ff.

29 See Joyner, Interpreting the Nuclear Nonproliferation Treaty (n 17) 84-87. For a contrary view in which the right to peaceful nuclear energy use in the NPT, art IV(1), is marginalised and stressed to be conditional, see John Duncan, 'Statement on behalf of China, France, the Russian Federation, the United Kingdom of Great Britain and Northern Ireland, and the United States of America to the 2008 Non-Proliferation Treaty Preparatory Committee' (9 May 2008) <http://ploughshares.ca/wp-content/uploads/2012/09/ NWSStatementMay908.pdf $>$ accessed 3 April 2016, delivered by Ambassador John Duncan, UK Ambassador for Multilateral Arms Control and Disarmament:

We note that a growing number of States Party is showing interest in developing nuclear programmes aimed at addressing their long-term energy requirements and other peaceful purposes. We are ready to co-operate with States Party in the development of nuclear energy for peaceful uses and we emphasise the requirement for compliance with non-proliferation obligations and for development of research, use and production of nuclear energy to be solely for peaceful purposes. We believe such international co-operation should contribute to the full implementation of the NPT and enhance the authority and effectiveness of the global non-proliferation regime. We welcome the work of the International Atomic Energy Agency on multilateral approaches to the nuclear fuel cycle and encourage efforts towards a multilateral mechanism to assure access for all countries to nuclear fuel services as a viable alternative to the indigenous development of enrichment and reprocessing. 
Thus, the fundamental right to peaceful nuclear energy is certainly not an absolute or unqualified right. The final words of article IV(1) of the NPT serve to limit the right to peaceful nuclear energy, ie to applications that do not result in the manufacture or other acquisition of nuclear weapons. Though possibly appearing redundant as a limitation on something already named a 'right to peaceful nuclear energy', this understanding of circumscription of the right is important, firstly, in making the case that it is a sufficiently defined right of states and, secondly, when attention turns to the juridical implications and applications of the right.

The second interpretive point that I would like to briefly address concerns one particular element of the nuclear fuel cycle-uranium enrichment. Enriched uranium, fabricated into fuel rods, is the standard fuel for the most common type of nuclear power reactors (light-water reactors). The enrichment of uranium can be accomplished through a number of different technical processes, but the most common is the gaseous centrifuge method, in which an amount of uranium oxide is spun at high speeds inside of a series of centrifuges, resulting in the separation of uranium isotopes and the concentration in the end sample of the U235 isotope, which is the isotope capable of a sustained fission reaction. For most states that have an indigenous nuclear fuel cycle, uranium enrichment is an essential part of that fuel cycle.

The question has been raised whether the fundamental right to peaceful nuclear energy necessarily includes the right to uranium enrichment as a part of an indigenous nuclear fuel cycle. Opinions on this question have varied, with US officials, on the one hand, arguing that there is no 'right to enrichment' contained in the article IV(1) right. Officials from Iran, on the other hand, have maintained that, since uranium enrichment is a necessary part of a full indigenous nuclear fuel cycle and since the article IV(1) right would be seriously undermined to the point of mootness if uranium enrichment were not included by implication within the broader right it recognises, it must therefore be the case that there is a lesser-included right to uranium enrichment within the article IV(1) right. ${ }^{30}$ This latter view expressed by Iranian officials is the more persuasive view. ${ }^{31}$ As the text of article IV(1) of the NPT recognises, the scope of the right to peaceful nuclear energy to extend to the development of 'research, production and use of nuclear energy for peaceful purposes', the right to produce nuclear energy would, according to a plain reading, appear to encompass within it all of the fuel cycle steps necessary to the process of nuclear energy production, inclusive of uranium enrichment. While this interpretation has not been met with universal agreement, I will assume arguendo for

30 See Fredrik Dahl, 'Is there a "Right" to Enrich Uranium? Iran Says Yes, US No' Reuters (23 November 2013) <http://www.reuters.com/article/us-iran-nuclear-rights-idUSBRE9AL0R120131123> accessed 3 April 2016.

31 Daniel H Joyner, 'Does Iran have a Legal Right to Enrich Uranium? Yes' Iranian Diplomacy (21 November 2013) <http://www.irdiplomacy.ir/en/page/1924877/Does+Iran+Have+a+Legal+Right+to+Enrich+Uraniu m+Yes.html> accessed 3 April 2016. For an opposing view, see Michael Makovsky and Blaise Misztal, 'Iran Has No "Right" to Enrich Uranium' Wall Street Journal (8 July 2012) <http://www.wsj.com/articles/SB100 $01424052702304141204577508442031058860>$ accessed 3 April 2016. 
purposes of the current analysis that this interpretation of the application of the article $\mathrm{IV}(1)$ right is correct.

\subsection{Juridical implications}

This, then, brings me to a consideration of the juridical implications of the right of states in international law to peaceful nuclear energy, as has been argued herein. The first implication, as indicated above, is that this fundamental right of states creates an obligation of respect for the right of third parties, and for the right-holder's exercise of it-ie an obligation not to act in serious prejudice of that right or unduly restrict the right holder's exercise of the right.

This obligation of respect can potentially be seen to have both positive and negative dimensions. For the particular fundamental right of states at issue here, positive dimensions to the corresponding obligation of respect in third states are difficult to envision. For example, it might be argued that one positive dimension to this obligation in third parties would be an obligation on supplier states of nuclear energy technologies and materials to trade freely with all states seeking to acquire these materials and to impose no limitations on that free trade, including limits on private legal persons situated within their territories. On balance, however, this assertion seems excessive in its imposition on supplier states and on their own freedom of choice regarding trading partners in what are, admittedly, sensitive materials and technologies.

Most nuclear technology supplier states have mature export control systems established within their domestic law, and it is through these systems that decisions are made regarding the export of, for example, dual use items-these being items that can be used in both civilian nuclear energy programmes and in nuclear weapons programmes. There is no multilateral treaty governing or setting standards concerning these choices, for the simple reason that at the multilateral level states have never been able to agree on objective criteria to govern dual use export controls. The closest approximation of such a normative regime is contained in the legally non-binding guidelines and trigger list of the plurilateral NSG. ${ }^{32}$

This being said, it is notable that in article IV(2) of the NPT, the following provision appears addressed particularly to nuclear supplier states:

Parties to the Treaty in a position to do so shall also co-operate in contributing alone or together with other States or international organizations to the further development of the applications of nuclear energy for peaceful purposes, especially in the territories of nonnuclear-weapon States Party to the Treaty, with due consideration for the needs of the developing areas of the world.

32 See Daniel H Joyner, 'The Nuclear Suppliers Group: History and Functioning' (2005) 11(2) Intl Trade L \& Regulation 33. 
Thus, the drafters of the NPT found no problem with a general positive obligation being placed upon nuclear supplier states to contribute to the development of nuclear energy in the developing world. However, in the context of the NPT, this obligation may be explained by the essential quid pro quo nature of the Treaty, and it would seem tenuous to seek to impose this particular positive obligation upon all states, even those not party to the NPT, through the vehicle of the fundamental right of states to peaceful nuclear energy.

While a positive general obligation on all nuclear supplier states to permit unrestricted free trade in nuclear materials and technologies between their exporters and any desiring recipient seems excessive, perhaps a distinguishable yet similar principle can be enunciated in a negative sense, ie perhaps the obligation to respect the right of states to peaceful nuclear energy can be best expressed as a negative obligation in third parties not to unduly restrict, through arbitrary or unreasonable means, the access of states to normal, lawful markets in civilian nuclear energy materials and technologies, through export controls or other means. Cast in this fashion, such an obligation would appear to be a reasonable and proportionate definition of at least one aspect of the obligation of respect created by the fundamental right to peaceful nuclear energy.

Specifically, then, with regard to the NSG, this fundamental right of states to peaceful nuclear energy could be asserted by developing states to create a positive legal obligation for all states, including adherents to the NSG's guidelines, which would prohibit arbitrary or unreasonable restrictions on the supply of nuclear materials and technologies for peaceful nuclear programmes. This obligation would be particularly useful as it would impose a more specific positive legal obligation, tailored to correspond with the particular contours of the fundamental right of states to peaceful nuclear energy, than any that otherwise exists in the sources of international legal obligation relative to peaceful nuclear energy technology trade. The fundamental right to peaceful nuclear energy could thereby be used potentially as a sword to strike down as unlawful actions of supplier states that are not in harmony with this corresponding obligation on third parties.

\subsection{Conflict with obligations}

But what about cases in which the fundamental right to peaceful nuclear energy comes into direct conflict with international legal obligations, either held by the right holder itself or by some other actor? What are the juridical implications of a right of states in such a case?

In the particular context of nuclear energy, this question is not simply hypothetical. Having received a report from the IAEA finding Iran to be non-compliant with its safeguards agreement with the agency on 31 July 2006, the UN Security Council adopted Resolution 1696 in which, acting under article 40 of chapter VII of the UN Charter, it demanded that Iran suspend all uranium enrichment related and 
reprocessing activities, and requested a report from the IAEA Director-General by 31 August to confirm this suspension. The Council followed up Resolution 1696 on 23 December 2006 with Resolution 1737, in which it acted under article 41 of the UN Charter and made binding the demands of Resolution 1696.

Iran's failure to abide by the terms of these resolutions, insisting that its activities are firmly within its rights under article IV(1) of the NPT, has led to the issuance of further Security Council resolutions pursuant to chapter VII, including a number of resolutions imposing trade restrictions and other economic sanctions upon Iran and upon specified Iranian individuals and business entities.

This case thus sets up an interesting conflict of norms. Iran essentially claims that it has a fundamental 'inalienable' legal right to peaceful nuclear energy which, for the reasons explained above, includes the right to uranium enrichment. Iran has, therefore, argued that the UN Security Council's command that Iran cease uranium enrichment is unlawful and ultra vires. ${ }^{33}$

In contrast, the UN Security Council's view is that its decisions are legally binding on Iran, due to Iran's status as a party to the UN Charter, which so provides in article 25. Thus, in the UN Security Council's view, its command that Iran cease uranium enrichment is lawful and is controlling over any conflicting right or obligation. Apologists for the UN Security Council's view on the matter have also cited article 103 of the UN Charter in support of its position. ${ }^{34}$

So, who is right? As a first analytical step, I would like to quickly dispose of the UN Charter article 103 argument. Article 103 is often misused and misunderstood. ${ }^{35}$ Article 103 provides: 'In the event of a conflict between the obligations of the Members of the United Nations under the present Charter and their obligations under any other international agreement, their obligations under the present Charter shall prevail.'

By the plain meaning of its terms, article 103 applies only to circumstances in which a state's obligations under the UN Charter come into conflict with its obligations under some other treaty. It is a simple conflict of treaty obligations provision that should be read narrowly. The issue under immediate consideration, by contrast, is a circumstance in which a state's obligations (ie Iran's) under the UN Charter have arguably come into conflict with the same state's legal right, not obligation; and furthermore a right that has been established independently in customary international law. Therefore, article 103 of

33 Permanent Mission of the Islamic Republic of Iran to the Agency, 'Communication regarding the Report of the Director General on Implementation of the NPT Safeguards Agreement and Relevant Provisions of Security Council Resolutions in the Islamic Republic of Iran' (22 March 2012) INFCIRC/837 (30 March 2012) <https://www.iaea.org/sites/default/files/publications/documents/infcircs/2012/infcirc837. pdf $>$ accessed 3 April 2016.

34 See Ryan Goodman, 'Iran's Purported "Right" to Enrich Uranium, and Alleged Bias at the New York Times' (Just Security, 19 November 2013) <https://www.justsecurity.org/3338/irans-purported-rightenrich-uranium-alleged-bias-york-times/> accessed 3 April 2016.

35 See Ryan Goodman, 'Expert Opinion on Iran's "Right” to Enrich Uranium in the Face of Security Council Resolutions' (Just Security, 20 November 2013) <https://www.justsecurity.org/3505/expert-opinion-iranright-enrich-uranium-security-council-resolutions-1696-1737/> accessed 3 April 2016. 
the UN Charter, according to the plain meaning of its terms, as well as by reference to its travaux préparatoires, is simply not applicable to the current matter. ${ }^{36}$

In essence, then, what we are left with is a conflict between, on the one hand, a legal right of a state which creates an obligation of respect to third parties that is based in customary international law-and is therefore binding upon states as well as upon the UN Security Council as an organ of an international organisation-and, on the other hand, a hierarchically equal jus dispositivum obligation binding upon the right-holding state (article 25 of the UN Charter). ${ }^{37}$

In the context of an international organisation exercising its authority under a treaty, such as the UN Security Council, the obligation created by the fundamental right of states to peaceful nuclear energy should be understood to create a corollary obligation in the international organisation to respect this right, and specifically not to be arbitrary, unreasonable, or disproportionate in the exercise of its treaty powers relative to this right.

This is a very similar conclusion to what has been argued in the context of the obligations of the UN Security Council relative to international human rights law in the exercise of its treaty powers. There is a solid basis in scholarly literature for the proposition that, notwithstanding that the UN Security Council is not itself a party to international human rights treaties, it is bound by customary international law-based obligations of respect for human rights when it exercises its treaty-based powers, including its powers under chapter VII of the UN Charter. ${ }^{38}$ I am essentially making the same argument, only in the context of fundamental rights of states that have created similar customary international law-based corollary obligations in third party holders of international legal personality.

Such an understanding of the obligations incumbent upon the Security Council and other international organisations created by fundamental rights of states would be potentially transformative in the authority dynamic as between such international organisations and particularly developing states. It would provide a justiciable standard against which to measure such international organisations' actions for lawfulness in areas in which states have asserted and have evidenced through state practice and opinio juris their acceptance of the existence of fundamental rights of states, including in areas in which such international organisations do not otherwise have legal obligations limiting their conduct with respect to these subject areas. It would give states a basis upon which to potentially challenge actions taken by the Security Council as being in violation of its

36 See Andreas Paulus, 'Article 103' in Bruno Simma and others (eds), The Charter of the United Nations: A Commentary (OUP 2012) vol II, 2132-33: 'The wording of art 103 suggests that it only applies to treaties and other agreements, not to customary international law. The travaux préparatoires support this view. The drafters refused to adopt a formula that explicitly included customary international law and other legal sources.'

37 August Reinisch, 'Developing Human Rights and Humanitarian Law Accountability of the Security Council for the Imposition of Economic Sanctions' (2001) 95 AJIL 851.

38 See, eg, Reinisch (n 37); Christopher Michaelsen, 'Human Rights as Limits for the Security Council: A Matter of Substantive Law or Defining the Application of Proportionality?' (2014) 19 J Conflict \& Security L 451 . 
obligation to respect the specific rights of states, just as it can be challenged as having acted in violation of specific rules of international human rights law.

So how would this work in the specific context of Iran's asserted fundamental right to peaceful nuclear energy, inclusive of a right to uranium enrichment, versus the Security Council's command through a legally binding resolution that Iran ceases uranium enrichment? The Security Council should be understood to be subject to a customary international law-based obligation to respect Iran's established right, by not acting in a manner that is arbitrary, unreasonable, or disproportionate in the exercise of its treaty powers relative to the right. The legal standard having been established, the question would then become one of application of law to facts, ideally conducted by an international judicial body of lawful jurisdiction, though, in the likely absence of this, by the analyst.

What, then, of Iran's article 25 of the UN Charter obligation to comply with the decisions of the Security Council? It is important to recall that article 25 in fact provides that member states are obliged to 'accept and carry out the decisions of the Security Council in accordance with the present Charter'. This provision has been interpreted by some scholars to require member state compliance only with decisions of the Security Council that are themselves in compliance with the provisions and principles of the UN Charter. ${ }^{39}$ This interpretation is strengthened by a view of article 25 in its context within the UN Charter, and in particular by the text of article 24. Article 24 provides that ' $\mathrm{i}] \mathrm{n}$ discharging these duties the Security Council shall act in accordance with the Purposes and Principles of the United Nations'.

In article 1 of the UN Charter, one of these purposes is identified as follows:

To maintain international peace and security, and to that end: to take effective collective measures for the prevention and removal of threats to the peace, and for the suppression of acts of aggression or other breaches of the peace, and to bring about by peaceful means, and in conformity with the principles of justice and international law, adjustment or settlement of international disputes or situations which might lead to a breach of the peace. ${ }^{40}$

Thus, the obligation on UN member states to accept and carry out the decisions of the Security Council' is intrinsically linked to the UN Security Council itself acting in accordance with the purposes and principles of the UN, one of the foremost of which is to act in accordance with international law. Furthermore, there is, as previously noted, an ascendant understanding by both scholars and international judicial bodies, that the UN Security Council's powers are limited not only by the provisions of the UN Charter itself, but also by customary international law. ${ }^{41}$

39 See Daniel H Joyner, 'Non-proliferation Law and the United Nations System: Resolution 1540 and the Limits of the Power of the Security Council' (2007) 2 LJIL; Anne Peters, 'Article 25' in Bruno Simma and others (eds), The Charter of the United Nations: A Commentary (OUP 2012) vol I, 807-19.

40 Emphasis added.

41 See, eg, Peters (n 39) 819; Antonios Tzanakopoulos, Disobeying the Security Council: Countermeasures against Wrongful Sanctions (OUP 2011). 
There are several different procedurally-related arguments as to exactly how it should be understood to occur, but on the basis of the foregoing there is an essential ascendant understanding that states party to the UN Charter and to article 25 thereof are at legal liberty not to comply with decisions of the UN Security Council that are themselves in disharmony with its legal obligations under customary international law. ${ }^{42}$ According to this understanding, if it were to be determined that the UN Security Council through its decisions violated its obligation to respect Iran's fundamental right to peaceful nuclear energy, Iran would be at legal liberty not to comply with the Security Council's command that it ceases uranium enrichment.

\section{Conclusion}

It is not the object of the current paper to provide a full analysis of the conflict between Iran and the UN Security Council relative to Iran's uranium enrichment activities. Rather, the object of this article has been to discuss both how the concept of fundamental rights of states should be understood as a matter of international legal theory and how it can be illustrated in essential terms in the particular context of the asserted right to peaceful nuclear energy, as codified in the NPT.

In my opinion, the concept of fundamental rights of states and the questions asked by the articles in this special issue go straight to the heart of the very modern struggle for the soul of the international legal system. Over the past two decades, the rise to prominence in the role of international organisations as fora not only for coordination of state action but also for lawmaking, monitoring and verification of state conduct and in some cases adjudication of legal disputes, has made the international legal system a very different, more complex place than it once was for states who were the only and independent actors within it. ${ }^{43}$

This modern structure of the international legal system, in which the legal obligations of states are often made, monitored, adjudicated, and enforced through international organisations, has taken on post-Westphalian aspects of constitutionalism and maturity as a legal system that have changed significantly the position of states. Indeed, a number of scholars have recently recognised international organisations as agents in which a decay in the traditional paradigm of state consent in international law-making has taken place. $^{44}$

42 See Tzanakopoulos (n 41); Daniel H Joyner, 'The Security Council as a Legal Hegemon' (2012) 43 Georgetown J Intl L 225.

43 See, eg, Dan Sarooshi, International Organisations and their Exercise of Sovereign Powers (OUP 2005).

44 See Nico Krisch, 'The Decay of Consent: International Law in an Age of Global Public Goods' (2014) 108 AJIL 1; Laurence R Helfer, 'Nonconsensual International Lawmaking' [2008] U Illinois L Rev 71; Andrew T Guzman, 'Against Consent' (2012) 52 Virginia J Intl L 747; Joel P Trachtman, The Future of International Law: Global Government (CUP 2013). 
As the international legal system matures, grows increasingly complex, dense and fragmented, and moves towards a more complete legal system, it would appear to be manifestly sensible and necessary for states, and particularly developing and less powerful states, to have not only clearly developed understandings of their obligations within that legal system, but also clearly developed understandings of their rights within that system which can potentially be used as a shield against excessive encroachment upon their sovereign independence by other actors.

In particular, the UN Security Council is one of the most legally influential of these international organisations (or, in its specific case, one organ of an international organisation). The Council's understanding of its role and powers and the question of the legal limits of those powers under the UN Charter is a subject that has been widely debated by international legal scholars in recent years. ${ }^{45}$ In writing on this subject, I have previously argued that the UN Security Council's understanding of its authority under the UN Charter has changed significantly since the end of the Cold War to encompass not only its more traditional executive role in enforcing existing international law, but also an ascending legislative and adjudicatory role that has greatly expanded both the scope and substance of its decisions, and has brought its actions into conflict with fundamental principles of international law. ${ }^{46}$

In light of the increased scope of action and self-understanding of authority of the UN Security Council in particular, all UN member states would appear to have a strong self-interest in developing and clarifying the concept of the fundamental rights of states in international law_rights which can be asserted against and which must be respected by other actors, including the UN Security Council. This is especially true for developing states, which are particularly susceptible to economic and financial sanctions imposed by the UN Security Council, as well as unilaterally by powerful states.

This susceptibility has been significantly amplified in recent decades due to the increased internationalisation of markets and interdependence of national economies, a phenomenon often referred to as globalisation. Globalisation has made developing states more vulnerable than ever before to both unilateral and collective sanctions imposed by, and often coordinated between, powerful states, the most powerful of which sit as permanent members on the UN Security Council. For developing states, therefore, there would seem to be a particular modern imperative to balance the scales of this phenomenon through the development and clarification of fundamental legal rights, which in turn create in other states and international organisations an obligation to respect these rights. ${ }^{47}$

45 See, eg, Tzanakopoulos (n 41); Erika de Wet, The Chapter VII Powers of the United Nations Security Council (Hart Publishing 2004); David Schweigman, The Authority of the Security Council under Chapter VII of the UN Charter (Kluwer Law International 2001).

46 Joyner, 'The Security Council as a Legal Hegemon' (n 42).

47 See UNGA Res 66/186 (22 December 2011). 